\title{
A Purified Serum Glycopeptide from Controls and Cystic Fibrosis Patients. II. Comparison of their Immunologic Properties Using Monoclonal Antibodies
}

\author{
MIRIAM G. BLITZER AND EMMANUEL SHAPIRA ${ }^{(25)}$
}

The Hayward Genetics Center, Departments of Pediatrics and Pathology, Tulane University School of Medicine, New Orleans, Louisiana, USA

\begin{abstract}
Summary
The immunogenic and antigenic properties of the cystic fibrosis glycopeptide and its normal counterpart were compared. BALB/c mice were immunized with either the cystic fibrosis glycopeptide or its normal counterpart and their spleen cells fused with X63NS1/1-Ag-4 (NS1) mouse myeloma cells. Four hybridization experiments (two with each glycopeptide) were performed in which different plating methods and screening assays were evaluated. Although an identical immunization procedure was used, 51 hybridoma cultures producing specific antibodies to the control glycopeptide and only 11 producing antibodies to the cystic fibrosis glycopeptide were obtained. Many of the monoclonal antibody preparations showed specificity toward the carbohydrate moiety of the glycopeptides and crossreacted immunologically with various glycoprotein preparations, whereas some were specific to the glycopeptides. The antibodies from the cloned hybridomas specific to the glycopeptide were used to compare serum fractions from controls and cystic fibrosis patients (10 samples in each group). Indistinguishable immunologic reactivity (antigenicity) between the controls and cystic fibrosis patients was demonstrated with the various monoclonal antibodies so far evaluated.
\end{abstract}

\section{Speculation}

Although these findings indicate that the cystic fibrosis glycopeptide and its normal counterpart differed markedly in their ciliary dyskinetic activity and in their immunogenicity, they revealed both structural and antigenic similarity.

The presence of a cystic fibrosis (CF)-specific factor affecting the rhythmic beat of cilia from rabbit tracheal explants was first described in 1967 by Spock et al. (17). These authors documented this biological activity (ciliary dyskinesia) in both CF sera and the euglobulin fraction of both patients and CF obligate heterozygotes. This phenomenon was not observed in sera and the euglobulin fraction from most controls. Recently (2) we purified a glycopeptide with a molecular weight of 4600 from sera of CF patients. This purified fraction caused marked mucociliary dyskinetic activity on rabbit tracheal explants. Using the same methodology, a similar glycopeptide with a molecular weight of 5700 was purified from sera of controls. This "normal counterpart" did not show any apparent biological activity on the rabbit tracheal explants, even in a 50-fold higher concentration. In both the $\mathrm{CF}$ and control glycopeptides, the protein components revealed the absence of aromatic amino acids, and the carbohydrate component was shown to be deficient in sialic acid (2).

Attempts to develop a quantitative, specific immunoassay to detect Spock's ciliary dyskinetic factor in order to detect CF patients and heterozygotes have not been afforded much success. In 1968, Tannenbaum (18) attempted to produce an antibody toward this factor. Antiserum was produced in rabbits using partially purified factor, yet no specific antibodies toward the factor were detectable after adsorption with control serum (18). Recently, using a similar methodology with guinea pigs, a specific antiserum to the CF-protein $(22,23)$ was obtained by Manson and Brock (13). The antisera obtained postimmunization was adsorbed with sera from controls and was tested for specificity toward the $\mathrm{CF}$-protein by rocket immunoelectrophoresis: The antiserum reaction seen was small but demonstrated a positive reaction with sera from 16 of $17 \mathrm{CF}$ homozygotes, eight out of nine heterozygotes, and one of 15 normal controls (13). Similar results were described by Wilson (20) after immunizing mice with the CFprotein.

In the present study, we used the hybridoma technique $(9,10)$ in an attempt to obtain specific monoclonal antibodies toward the purified glycopeptide with ciliary dyskinetic activity from $\mathrm{CF}$ patients and toward its normal counterpart (2). The advantage of having a continuous, unlimited supply of monoclonal antibody with a defined specificity toward an antigenic determinant will avoid the methodologic problems encountered by antisera adsorption. By immunizing with both the CF glycopeptide and its normal counterpart, the immunogenic and antigenic properties of these preparations were compared.

\section{MATERIALS AND METHODS}

Materials. Diethylaminoethyl (DEAE)-cellulose (Cellex-D) was obtained from Bio-Rad Laboratories (Richmond, CA). Hypoxanthine, thymidine, aminopterin, Tween 20, sepharose-4B, and Sephadex G-100 were from Sigma Chemical Company (St. Louis, MO). Dulbecco's Modified Eagle's Medium (DMEM), fetal calf serum, and Freund's complete adjuvant were from GIBCO (Grand Island, NY). Rabbit antiserum to mouse immunoglobulin $\mathrm{G}$ ( $\operatorname{lgG}$ ), peroxidase conjugated (lot 14453), was from Cappel Laboratories (Cochranville, PA) and rabbit antiserum to human $\mathrm{IgG}$ was from Calbiochem-Behring Corporation (La Jolla, CA). Iodine-125 [ $\left.{ }^{125} \mathrm{I}\right]$ Radioiodination System Kit was purchased from New England Nuclear Company (Rochester, NY). Polyethylene glycol was from Serva Chemical Company (Heidelberg, Germany) and pristane $(2,6,10,14$-tetramethylpentadecane) was purchased from Aldrich Chemical Company (Milwaukee, WI). BALB/c mice were from Jackson Laboratories (Bar Harbor, ME). The mouse myeloma cells, X63NS1/1-Ag-4 (NS1), and the purified goat antibodies to mouse IgG were kindly obtained from Dr. Z. Eshhar, Weizmann Institute. The following purified glycoprotein preparations were obtained: fetuin, ovalbumin, and bovine submaxillary mucin from Sigma Chemical Company, ribonuclease-B and rabbit seromucoid from Worthington Biochemical Corporation (Freehold, $\mathrm{NJ}$ ), bovine transferrin from Miles Biochemicals (Elkhart, IN), and $\alpha_{1}$-acid glycoprotein from the American Red Cross. All other reagents were either reagent grade or the best grade available. 
Serum and serum fractions. Blood specimens $(1-15 \mathrm{ml})$ were obtained after signed, informed consent. Specimens were obtained from healthy volunteers with no family history of CF (age range from $14-30$ years), from $C F$ patients (from ages 2-26 years), and from obligate $C F$ heterozygotes (ages $25-35$ years). The clinical diagnosis of $C F$ was confirmed by repeated sweat electrolyte analyses (sweat chloride: $70-105 \mathrm{meq} / \mathrm{liter}$ ). All patients are followed and managed by the Louisiana CF Clinic. The blood was incubated for $30 \mathrm{~min}$ at $37^{\circ} \mathrm{C}$, the clot separated and retracted for $3 \mathrm{~h}$ at $4^{\circ} \mathrm{C}$. The serum was separated by centrifugation and stored at $-20^{\circ} \mathrm{C}$ until use.

The IgG fractions from the serum samples were obtained by DEAE-cellulose column chromatography with $0.01 \mathrm{M}$ potassium phosphate buffer, $\mathrm{pH} 8.0$, followed by Sephadex G-100 gel filtration in $0.05 \mathrm{M}$ sodium phosphate buffer, $\mathrm{pH}$ 7.4. The purified glycopeptide preparations from controls and CF patients were obtained as previously described (2). The samples were compared in a double-blind manner for ciliary dyskinetic activity on rabbit tracheal explants (2). All glycopeptide preparations from $\mathrm{CF}$ patients revealed ciliary dyskinetic activity, whereas the preparations from controls showed no biological activity on the explants.

Insoluble immunosorbents. Human IgG fraction was covalently bound to cyanogen bromide activated sepharose-4B (15). This immunoadsorbent was used to adsorb antibodies cross-reacting with human $\operatorname{IgG}$ from the purified goat antibodies to mouse $\operatorname{IgG}$ and from the peroxidase-conjugated rabbit antisera to mouse IgG. The same immunoadsorbent was used to purify rabbit antibodies to human $\mathrm{IgG}$. Rabbit antisera to human $\mathrm{IgG}$ was adsorbed and the purified antibody eluted with $0.1 \mathrm{M}$ acetic acid followed by exhaustive dialysis with phosphate buffered saline $(0.14 \mathrm{M}$ sodium chloride in $0.01 \mathrm{M}$ phosphate buffer, $\mathrm{pH} 7.0$; PBS) and concentration by negative pressure ultrafiltration.

Immunization of mice. One $\mathrm{ml}$ of the purified glycopeptide (from CF patients or controls), $0.5 \mathrm{mg} / \mathrm{ml}$ by Lowry (12), was emulsified with one $\mathrm{ml}$ of Freund's complete adjuvant. BALB/c female mice were injected with $150 \mu \mathrm{l}$ of the emulsion into their footpads. After $2 \mathrm{wk}$, the mice received a booster injection of the same emulsion, $100 \mu \mathrm{l}$ into the footpads and $150 \mu \mathrm{l}$ intramuscularly. Two wk later, blood specimens were obtained from the retro-orbital plexus, and circulating antibodies against the purified glycopeptides were measured using solid phase radioimmunoassay (RIA). Circulating antibodies were revealed in all the immunized mice, and the mice then received an intravenous booster of 100 $\mu \mathrm{l}$ of the purified glycopeptide $(0.5 \mathrm{mg} / \mathrm{ml}$ in PBS, $\mathrm{pH} 7.0)$. Three days later, the animals were sacrificed, spleens removed aseptically and used for hybridization.

Hybridoma production and plating techniques. Cell hybridization of the spleen cells from the immunized mice with the NSI myeloma cells, using polyethylene glycol, was performed as previously described $(5,6)$. Selection of the spleen lymphocyte-myeloma hybrids was performed using hypoxanthine-aminopterin-thymidine (HAT) in DMEM medium (DMEM containing $15 \%$ fetal calf serum supplemented with l-glutamine, sodium pyruvate, antibiotics, and fungizone). In the first set of fusions the cells were suspended to a final concentration of $2.5-4.1 \times 10^{4}$ viable cells per $\mathrm{ml}$, and $2 \mathrm{ml}$ aliquots were distributed in 24-well Costar plates (\#3524; Costar, Cambridge, MA). In the second set of fusions, the cells were suspended to a final concentration of $1.4-2.0 \times 10^{5}$ cells per $\mathrm{ml}$ and were distributed in $150 \mu \mathrm{l}$ aliquots into 96-well microculture plates (\#3596; Costar)

Cloning on semisolid agarose. Cloning of the hybridomas was performed on $0.3 \%$ soft agarose medium, as previously described (3). The hybridoma cells were grown on the agarose-medium for approximately 7-10 days. Colonies of cells were picked using sterile pasteur pipettes and transferred to 96-well microculture plates. Subclones producing specific antibodies were then transferred into 2-ml DMEM culture media in the 24-well Costar plates, screened again for antibody production and transferred into $10-\mathrm{ml}$ DMEM culture media in $100 \times 20 \mathrm{~mm}$ sterile petri dishes. Monoclonal antibodies from these media were either used directly for experiments or were isolated by precipitation with ammonium sulfate at $45 \%$ saturation. Mouse $\mathrm{IgG}$ antibodies in these fractions were characterized by immunoelectrophoresis against goat antisera to mouse IgG, as previously described (2).

Growing hybridomas in mice. The cultured hybridoma cells (2$3 \times 10^{7}$ ) were injected intraperitoneally into BALB/c mice that were primed 3-5 wk earlier with an intraperitoneal injection of $0.5 \mathrm{ml}$ pristane. Ascites fluid containing $4-6 \mathrm{mg} / \mathrm{ml}$ monoclonal antibodies was obtained 2-3 wk later by abdominal puncture.

Screening for antibody production. Solid phase radioimmunoassay $(R I A)$ : A solid-phase RIA on polyvinyl chloride plates (Dynatech Laboratories, Inc.; Alexandria, VA) was used to assay for antibodies (19). Plates were coated with the antigen by incubating with $100 \mu \mathrm{l}$ antigen per well, $50 \mu \mathrm{g} / \mathrm{ml}$, at room temperature for 1 h. The plates were washed three times with PBS containing $0.5 \%$ bovine serum albumin (BSA) and $0.02 \%$ sodium azide (PBS/ BSA), and $100 \mu \mathrm{l}$ of the hybridoma culture media was added and incubated for $1 \mathrm{~h}$ at room temperature. After this incubation, the plates were washed three times with PBS/BSA, and $100 \mu \mathrm{l}$ of the second antibody, purified goat antibodies to mouse $\operatorname{IgG},\left[{ }^{12.5} \mathrm{I}\right]$ labeled, were added. These purified goat antibodies to mouse IgG (human IgG adsorbed) were iodinated with $\left[{ }^{125} \mathrm{I}\right]$ using the Radioiodination System Kit and diluted to a final concentration of $0.2 \mu \mathrm{g} / \mathrm{ml}, 92.2 \times 10^{3} \mathrm{cpm} / \mu \mathrm{g}$, in PBS/BSA. The plates were incubated for $1 \mathrm{~h}$ at room temperature with this second antibody, and after washing four times with PBS/BSA, the individual wells were cut and counted in a Beckman 8000 Gamma Counter. Both media from NS1 myeloma cultures and PBS/BSA were used as blanks. The hybridoma cultures were first screened with the homologous IgG fraction, and once a cell culture was revealed to be positive, it was confirmed with the homologous glycopeptide. In order to determine the amount of antigen (purified glycopeptide or IgG fraction from controls or $\mathrm{CF}$ patients or purified rabbit antibodies to human IgG) bound to the solid phase, the wells were coated with $100 \mu \mathrm{l}$ antigen, $50 \mu \mathrm{g} / \mathrm{ml}$, and after washing with PBS, $\left.{ }^{125} \mathrm{I}\right]$-labeled BSA was added. The extent of binding of the iodinated BSA to the antigen-coated wells was compared to that of wells coated with $\left[{ }^{125} \mathrm{I}\right]$-labeled BSA (arbitrarily defined as $100 \%$ binding). It was shown that the $\mathrm{IgG}$ preparations from controls and CF patients as well as purified rabbit antibodies to human IgG bound to $96-98 \%$ of the binding sites, whereas the purified glycopeptide preparations occupied only $30-40 \%$ of the binding sites. Using a higher concentration of the glycopeptides did not increase its binding.

Screening for antibody production. Enzyme-linked immunosorbent assay-ELISA (7): This assay was identical to the solid-phase RIA described above, but the plates were washed four times with PBS containing 0.05\% Tween 20 (PBS/Tween 20), and as the second antibody, $100 \mu$ l of peroxidase-conjugated goat antibodies to mouse IgG (human IgG adsorbed, 1/1200 dilution) was used. After the last washing, $100 \mu \mathrm{l}$ of peroxidase substrate $(0.006 \%$ hydrogen peroxide and $0.01 \%$ ortho-dianisidine in $0.1 \mathrm{M}$ citratephosphate buffer, pH 5.0) were added. In the positive wells, yellow to brown color developed within 3-5 min. For some plates, screening was performed with both the solid-phase RIA and the solid-phase ELISA. Positive wells with the ELISA screen were those that had $300 \mathrm{cpm}$ or above with the RIA.

\section{RESULTS}

Antibody titers in the immunized mice. Four preparations of the purified glycopeptide, two from controls and two from CF patients, were used for immunization. Groups of three mice each were immunized with the four antigens. Three days before hybridization, the immunized mice were bled and the serum $(1 / 10$ dilution in PBS) tested for the presence of antibodies toward the purified glycopeptides using solid-phase RIA. The results from one set of mice are shown in Table 1. As shown in the Table, circulating antibodies of the $\operatorname{IgG}$ type were documented in all mice. Significantly higher titers were shown in the group of mice immunized with the control glycopeptide as compared to those in the second group. In the mice immunized with the glycopeptide from $C F$ patients, the crossreactivity with the homologous antigen seemed better than with the heterologous antigen. 
Hybridomas producing antibodies toward the glycopeptides. Spleen lymphocytes from the four different groups of mice were hybridized with the NS1 myeloma cells. In the first set of fusion experiments (one group of mice immunized with the glycopeptide from a control and the second with the glycopeptide from a $\mathrm{CF}$ patient) the hybrid cells were plated in 24-well Costar plates; in the second set the cells were distributed in microtiter plates (see "Materials and Methods" for details). Screening for antibody production was begun 10 days after hybridization and repeated four times at 2-3 day intervals. The results are summarized in Table 2 . In both sets a significantly higher yield of antibodyproducing hybridomas was obtained with the control glycopeptide as compared to the glycopeptide purified from CF patients.

Wells containing antibody-producing hybridomas were transferred to 24-well Costar plates containing hypoxanthine and thymidine (HT, with no aminopterin) media and gradually into media without HT. These wells were shown to produce antibodies reacting with both the purified glycopeptide preparations and the IgG fractions. Each of these cultures was then screened with six IgG preparations: two from controls, two from CF patients, and two from obligate heterozygotes. Indistinguishable immunologic reactivity was demonstrated between each of the various antibodyproducing hybridomas tested and the different IgG preparations. The results of some of these experiments are shown in Table 3.

Antigenic specificity of the monoclonal antibodies. Twelve antibody-producing hybridomas, eight obtained from the immunization with the control glycopeptide and four with the CF glycopeptide, were chosen for further studies. These were cloned on semisolid agarose, and antibody-producing clones were selected. The antibodies were separated from media using ammonium sulfate fractionation, and the subcloned hybridoma cells were injected intraperitoneally into pristane-sensitized mice. The monoclonal antibodies obtained were compared to mouse serum IgG fraction by immunoelectrophoresis. The results are shown in Figure 1. Each of the various hybridomas matched a narrow section from the serum IgG immune precipitin arc. Within the IgG electrophoretic range, the hybridomas differed in their mobilities. The antigenic specificity of the cloned hybridoma antibody preparations toward the purified glycopeptides and IgG preparations (control and $\mathrm{CF}$ ) and toward seven, commercially available, purified gly-

Table 1. Circulating antibodies from mice immunized with the purified glycopeptide from control or cystic fibrosis patient, using solid-phase radioimmunoassay ( $\mathrm{cpm} /$ well)

\begin{tabular}{|c|c|c|c|c|c|c|}
\hline \multirow[b]{4}{*}{ Antigen tested } & \multicolumn{6}{|c|}{$\begin{array}{l}\text { Serum from mice immunized with glycopep- } \\
\text { tide from }\end{array}$} \\
\hline & Cystic & $\begin{array}{l}\text { fibro } \\
\text { tient }\end{array}$ & s pa- & & Contro & \\
\hline & \multicolumn{3}{|c|}{ Mouse No. } & \multicolumn{3}{|c|}{ Mouse No. } \\
\hline & I & 2 & 3 & 1 & 2 & 3 \\
\hline $\begin{array}{l}\text { Purified glycoper ide from } \\
\text { controls }\end{array}$ & 151 & 190 & 105 & 1601 & 1938 & 1609 \\
\hline $\begin{array}{l}\text { Purified glycopeptide from } \\
\text { cystic fibrosis patient }\end{array}$ & 727 & 587 & 901 & 1922 & 2280 & 2096 \\
\hline
\end{tabular}

Table 3. Immunologic cross-reactivity of monoclonal antibody preparations with IgG fractions, using solid-phase radioimmunoassay ( $\mathrm{cpm} /$ well)

\begin{tabular}{lcccc}
\hline & \multicolumn{4}{c}{$\begin{array}{c}\text { Antibody } \\
\text { cultures }\end{array}$} \\
\cline { 2 - 5 } & C-I & C-X & C-XII & CF-II \\
\hline IgG preparations from & & & & \\
Control & 2194 & 1983 & 2060 & 2122 \\
$\quad 1$ & 2257 & 2097 & 2247 & 2158 \\
2 & & & & \\
Cystic fibrosis & 2310 & 2202 & 2232 & 2204 \\
1 & 2345 & 2216 & 2149 & 2300 \\
2 & & & & \\
Obligate heterozygote & 2310 & 2306 & 2374 & 2264 \\
1 & 2086 & 2022 & 2336 & 2406 \\
2 & & & &
\end{tabular}

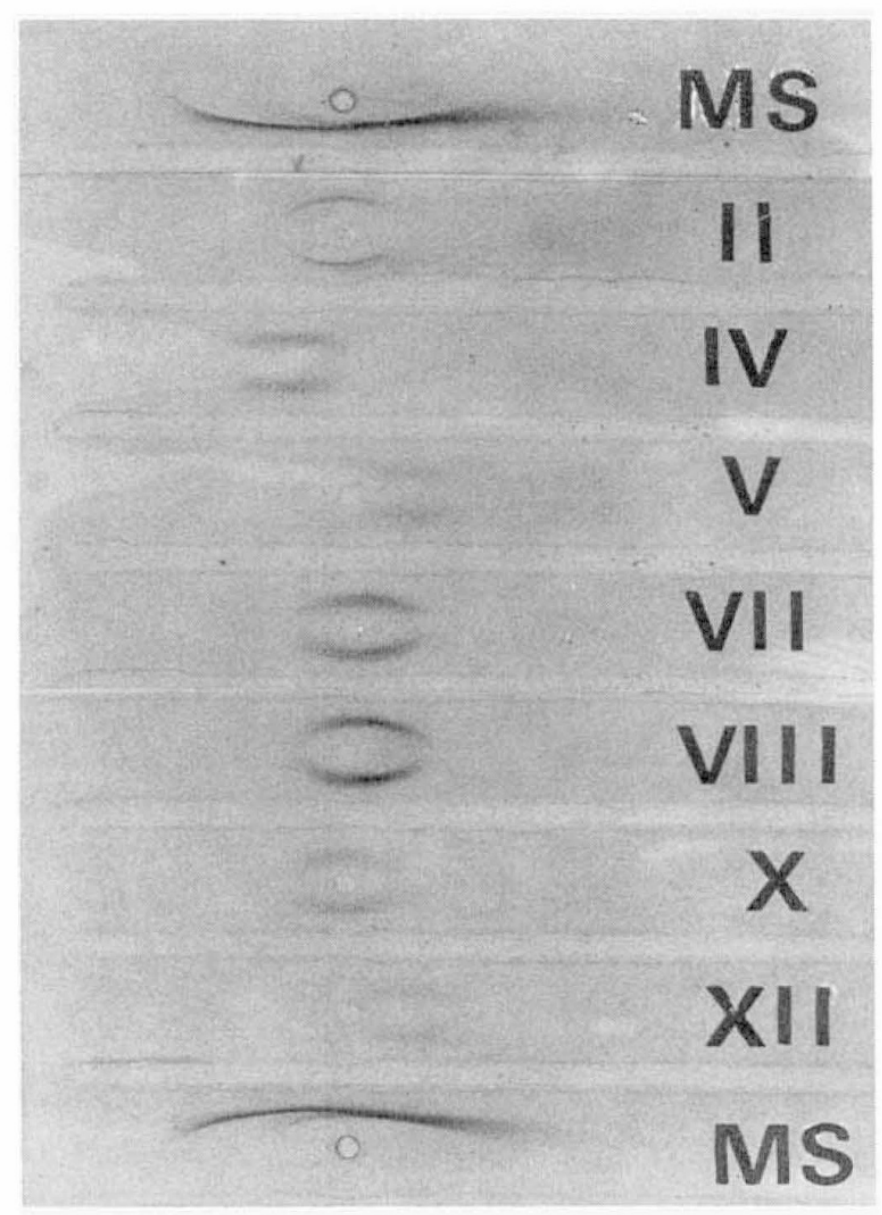

Fig. 1. Immunoelectrophoresis of various monoclonal antibody preparations (roman numerals, $1 \mathrm{mg} / \mathrm{ml}$ ) to the glycopeptide purified from control serum as compared to mouse serum (1/4 dilution). The troughs were filled with goat antiserum to mouse IgG.

Table 2. Summary of cell hybridization experiments

\begin{tabular}{|c|c|c|c|c|c|c|}
\hline \multirow[b]{2}{*}{$\begin{array}{c}\text { Hybridization } \\
\text { set }\end{array}$} & \multirow[b]{2}{*}{$\begin{array}{l}\text { Glycopeptide } \\
\text { used for } \\
\text { immunization }\end{array}$} & \multirow[b]{2}{*}{$\begin{array}{l}\text { Number } \\
\text { of wells }\end{array}$} & \multirow[b]{2}{*}{$\begin{array}{l}\text { Viable myeloma } \\
\text { (cells/well) }\end{array}$} & \multirow[b]{2}{*}{$\begin{array}{l}\text { Positive wells } \\
\text { for antibody } \\
\text { production }\end{array}$} & \multicolumn{2}{|c|}{ Yield } \\
\hline & & & & & $\begin{array}{l}\text { Positive wells } \\
\text { per } 10^{6} \text { cells }\end{array}$ & $\begin{array}{l}\% \text { positive } \\
\text { wells }\end{array}$ \\
\hline I & Cystic fibrosis 1 & 96 & $5.0 \times 10^{4}$ & 2 & 0.42 & 2.1 \\
\hline \multirow{2}{*}{ II } & Control 2 & 576 & $2.1 \times 10^{4}$ & 35 & 2.90 & 6.1 \\
\hline & Cystic fibrosis 2 & 576 & $3.0 \times 10^{4}$ & 9 & 0.52 & 1.6 \\
\hline Total & Cystic fibrosis & 672 & & 11 & & 1.6 \\
\hline
\end{tabular}


Table 4. Immunologic cross-reactivity of glycopeptide-specific antibody preparations with control and cystic fibrosis IgG fractions using a four-component solid-phase radioimmunoassay ( $\mathrm{cpm} /$ well)

\begin{tabular}{|c|c|c|c|c|}
\hline \multirow[b]{2}{*}{ Sample tested } & \multicolumn{4}{|c|}{ Antibody preparations from hybridoma clones } \\
\hline & C-I-92 & $\mathrm{C}-\mathrm{X}-12$ & C-XII-1 & CF-II-3 \\
\hline \multicolumn{5}{|l|}{ Control sera } \\
\hline 1 & 1178 & 1246 & 2026 & 2058 \\
\hline 2 & 1227 & 1344 & 2107 & 2316 \\
\hline 3 & 1186 & 1264 & 2260 & 1809 \\
\hline 4 & 1205 & 1315 & 1994 & 2248 \\
\hline 5 & 1170 & 1151 & 1977 & 2029 \\
\hline 6 & 1200 & 1071 & 2037 & 2122 \\
\hline 7 & 1153 & 1196 & 2060 & 1987 \\
\hline 8 & 1248 & 1136 & 2101 & 2107 \\
\hline 9 & 1121 & 1190 & 2008 & 2073 \\
\hline 10 & 1191 & 1086 & 1841 & 2111 \\
\hline mean & $1188 \pm 36$ & $1200 \pm 92$ & $2041 \pm 107$ & $2086 \pm 138$ \\
\hline \multicolumn{5}{|l|}{ Cystic fibrosis sera } \\
\hline 1 & 1306 & 1135 & 1961 & 2050 \\
\hline 2 & 1410 & 1151 & 1894 & 2177 \\
\hline 3 & 1307 & 1133 & 2067 & 2001 \\
\hline 4 & 1275 & 1164 & 2231 & 1930 \\
\hline 5 & 1381 & 1215 & 2019 & 2131 \\
\hline 6 & 966 & 1109 & 2181 & 1769 \\
\hline 7 & 1315 & 1211 & 1966 & 2009 \\
\hline 8 & 1362 & 1123 & 2096 & 2006 \\
\hline 9 & 1189 & 1181 & 1867 & 2109 \\
\hline 10 & 1142 & 1127 & 1984 & 2202 \\
\hline mean & $1265 \pm 133$ & $1155 \pm 37$ & $2027 \pm 118$ & $2038 \pm 128$ \\
\hline \multicolumn{5}{|l|}{ Student's } \\
\hline$t$ value & -1.77 & 0.16 & 0.28 & 0.81 \\
\hline$P$ value & $>0.1$ & $>0.7$ & $>0.8$ & $>0.4$ \\
\hline
\end{tabular}

coprotein preparations was determined using solid-phase RIA. From the 12 different antibody preparations examined, four revealed immunologic reactivity with the purified glycopeptides and IgG preparations but with none of the other glycoproteins, whereas eight showed immunologic reactivity with the purified glycopeptides, IgG fractions, as well as the glycoproteins tested.

Comparison of $\mathrm{Ig} G$ fractions from controls and $C F$ patients using glycopeptide-specific monoclonal antibodies. The four monoclonal antibody preparations reacting immunologically with the control and CF glycopeptides and IgG fractions but not with any of the other glycoproteins examined were used in the following experiment. In order to compare a large number of IgG fractions from controls and CF patients, a four-component RIA was used, as follows: purified rabbit antibodies to human $\mathrm{IgG}$ were applied to the wells of the microtiter plates $(100 \mu \mathrm{l} /$ well, $0.1 \mathrm{mg} / \mathrm{ml})$ and incubated for $1 \mathrm{~h}$ at room temperature. After washing the plates with PBS/BSA, $200 \mu \mathrm{l}$ serum from controls or CF patients $(1 / 20$ dilution in PBS) was applied and incubated for $1 \mathrm{~h}$ at room temperature. By this method, a constant amount of the IgG fraction from the serum was bound in each well. The specific monoclonal antibody preparations were added, followed by $\left[{ }^{[25} \mathrm{I}\right]$-labeled second antibody as described in the RIA procedure. The results are shown in Table 4 . No statistically significant differences were observed between the immunologic reactivity of the control and CF fractions with the monoclonal antibody preparations compared.

\section{DISCUSSION}

Recently we have described the purification and characterization of a serum glycopeptide from controls and CF patients. Both revealed marked structural similarities but differed significantly in their biological activity toward rabbit tracheal explants. These glycopeptide preparations were dissociated from $\mathrm{IgG}$ fractions with $8 \mathrm{M}$ urea and were purified by size fractionation and chromatography (2). In the present study, a significantly lower titer of circulating antibodies was determined in mice immunized with the glycopeptide from CF patients as compared to those immunized with its normal counterpart (Table 1). The circulating antibodies in mice immunized with the glycopeptide from $\mathrm{CF}$ patients showed significantly higher reactivity with this antigen than with its normal counterpart. The antibodies from mice immunized with the control glycopeptide revealed similar reactivity with both the control and CF glycopeptides (Table 1). The results in Table 1 seem to confirm a previous report (21) documenting circulating antibodies in mice immunized with ciliary dyskinetic substances. Encouraged by the evidence of circulating antibodies toward the glycopeptides and the differences in immunologic reactivity, hybridization experiments to obtain monoclonal antibodies were done.

Four hybridization experiments, two with each of the glycopeptide preparations, were performed. As shown in Table 2, a much higher yield of antibody-producing hybridoma cultures was obtained using the control glycopeptide as an immunogen when compared to the glycopeptide from CF patients. In the two sets of experiments (Table 2) different plating techniques were used. The observation of a significantly higher yield with the control glycopeptide was documented with both techniques. For each set of experiments, a different shipment of BALB/c mice (from Jackson Laboratories) was used. The mice were divided randomly into two groups, one immunized with the control glycopeptide and one with the glycopeptide from CF patients. An identical immunization procedure was used for all groups; thus, the possibility of individual variability seems highly unlikely. The observations summarized in Table 2 indicate that the control glycopeptide acts as a better immunogen when compared to the glycopeptide purified from CF patients.

Relatively low binding of the purified glycopeptides to the polystyrene microtiter plates used in the solid-phase RIA was observed. As these glycopeptides were dissociated from the IgG fraction of serum, this decreased binding of the purified glycopeptides was circumvented by using IgG as the antigen bound to the plastic. A technical problem we encountered using $\operatorname{IgG}$ as the antigen was its crossreactivity with purified goat antibodies to mouse IgG both in the solid-phase RIA and ELISA. This resulted in relatively high background that was fully corrected by adsorbing the second antibody with insolubilized human IgG. After such adsorption, the background was only $1-4 \%$ of the positive readings.

All the hybridomas obtained had similar immunologic reactivity with the IgG fractions from controls, CF patients, and obligate heterozygotes. Examples are shown in Table 3. Twelve hybridomas, eight from the immunization with the control glycopeptide and four from the immunization with the CF glycopeptide, were chosen and further subcloned. The antibody fractions of the subcloned hybridomas reacted immunologically with the purified glycopeptides and the IgG fractions from both controls and CF patients. In order to determine if the specificity of these monoclonal antibodies was toward the polypeptide component of the glycopeptide or toward the oligosaccharide moiety, their immunologic reactivity with seven different purified glycoproteins was tested. These glycoproteins were chosen in order to represent oligosaccharides linked to the polypeptide via either an $\mathrm{N}$-linkage or an O-linkage, as well as both "simple" and "complex" oligosaccharide chains (11). Eight of the 12 subcloned hybridoma antibody preparations reacted immunologically with all of the glycoproteins tested. This observation indicates that their specificity was directed against antigenic determinants of the oligosaccharides. Four of the 12 subcloned hybridomas revealed specificity only toward the glycopeptides and did not crossreact with any of the glycoproteins tested. This latter group of antibodies is most likely directed against antigenic determinants of the polypeptide component of the glycopeptide and not to the oligosaccharide portion. Indistinguishable immunologic reactivity was observed using these specific monoclonal antibody preparations with both $\mathrm{CF}$ and control purified glycopeptides and their IgG fractions. Very similar immurologic reactivity was shown when these monoclonal antibodies with restricted specificity were tested with a 
larger number of $\operatorname{IgG}$ fractions from control and $C F$ patients (Table 4).

Although antigenic identity was revealed between the CF glycopeptide and its normal counterpart (Tables 3 and 4), marked differences were observed in their immunogenicity (Tables 1 and 2). A possible explanation is that the altered immunogenicity reflects differences in the adjuvant effect of the oligosaccharide component of these preparations. Another explanation is that the dose of a polysaccharide immunogen required for antibody production versus that inducing immunologic tolerance in mice differs according to the size and structure of the carbohydrate component; thus, a different equilibrium between tolerance and immunogenicity was obtained with the two glycopeptide preparations. If the structural difference between the CF glycopeptide with the mucociliary activity and its normal counterpart is in their polysaccharide component, this might account for the differences in their immunogenicity. Different immunization protocols, where both $\mathrm{IgM}$ and $\mathrm{IgG}$ antibody production will be assessed, are necessary to reveal possible subtle antigenic differences. Another immunologic option to reveal such differences might be by inducing immunologic tolerance in newborn mice using either the $\mathrm{CF}$ or control glycopeptide and subsequently immunizing with the alternate glycopeptide.

The possibility of an abnormality in some aspect of glycoproteins as the underlying, inherited defect in $\mathrm{CF}$ has been suggested by many investigators $(1,4,8,14,16)$. We have previously suggested that the mucociliary activity observed in the glycopeptide purified from CF patients, absent in its "normal counterpart," might be a consequence of such a generalized phenomenon of abnormal synthesis or degradation in glycoproteins and glycopeptides (2). The present observation that the monoclonal antibodies directed toward the polypeptide component of the glycopeptide revealed antigenic identity with both the control and CF glycopeptides further supports the possibility that the mucociliary activity is secondary to differences in the structure of the oligosaccharide components.

\section{REFERENCES AND NOTES}

1. Alhadeff, J. A.: Glycoproteins and cystic fibrosis: A review. Clin. Genetics, 14: 189 (1978)

2. Blitzer, M. G. and Shapira, E.: A purified serum glycopeptide from controls and cystic fibrosis patients. I. Comparison of their mucociliary activity on rabbit tracheal explants. Pediatr. Res., 16: 203 (1982).

3. Coffino, P.. Baumal, R. Laskov, R., and Scharff, M. D.: Cloning of mouse myeloma cells and detection of rare variants. J. Cell. Physiol., 79: 429 (1972).

4. Dische, Z.. Pallavicini, J. C., Smirnow, N., and di Sant'Agnese. P. A.: Abnormalities in the composition of urinary nondialyzable glycoproteins in cystic fibrosis of the pancreas (CFP). Amer. J. Dis. Child., 102: 733 (1961).

5. Eshhar, Z., Blatt, C.. Bergman, Y., and Haimovich, J.: Induction of secretion of
IgM from cells of the $\mathrm{B}$ cell line $38 \mathrm{C}-13$ by somatic cell hybridization. J. Immunol., 122: 2430 (1979).

6. Galfre, G., Howe, S. C., Milstein, C.. Butcher, G. W., and Howard, J. C.: Antibodies to major histocompatibility antigens produced by hybrid cell lines. Nature, 266: 550 (1977).

7. Kearney, J. E., Radbruch. A., Liesegang, B., and Rajewsky, K.: A new mouse myeloma cell line that has lost immunoglobulin expression but permits the construction of antibody-secreting hybrid cell lines. J. Immunol., 123: 1548 (1979).

8. Knauff, R. E. and Adams, J. A.: Proteins and mucoproteins in the duodenal fluids of cystic fibrosis and control subjects. Clin. Chim. Acta, 19: 245 (1968).

9. Köhler, G. and Milstein. C.: Continuous cultures of fused cells secreting antibodies of predefined specificity. Nature (London), 256: 495 (1975).

10. Köhler. G. and Milstein. C.: Derivation of specific antibody-producing tissue culture and tumor lines by cell fusion. Eur. J. Immunol., 6: 511 (1976).

11. Kornfeld. R and Kornfeld, S.: Structure of glycoproteins and their oligosaccharide units. In: W. J. Lennarz: The Biochemistry of Glycoproteins and Proteoglycans. p. I (Plenum Press. New York, New York 1980).

12. Lowry. O. H., Rosebrough, N. J., Farr, A. L., and Randall, R. J.: Protein measurement with the Folin phenol reagent. J. Biol. Chem., 193: 265 (1951)

13. Manson, J. C. and Brock, D. J. H.: Development of a quantitative immunoassay for the cystic fibrosis gene. Lancet, $1: 330$ (1980).

14. Pearson. R. D. and Lubin, A. H.: Increased heparin binding in cystic fibrosis: a reflection of altered glycoprotein biosynthesis? Pediatr. Res., 13: 834 (1979).

15. Porath, J., Axen, R., and Ernback, J.: Chemical coupling of proteins to agarose. Nature, 215: 1491 (1967).

16. Shapira, E. and Menendez, R.: Increased binding of concanavalin A to $\alpha,-$ macroglobulin, $\operatorname{IgM}$ and $\operatorname{IgG}$ from cystic fibrosis plasma. Biochem. Biophys. Res. Comm.. 93: 50 (1980).

17. Spock, A., Heick, H. M. C., Cress, H., and Logan, W. S.: Abnormal serum factor in patients with cystic fibrosis of the pancreas. Pediatr. Res., $1: 173$ (1967).

18. Tannenbaum, R.: Immunological studies of the "Spock" cystic fibrosis-factor. Masters of Science Thesis, Weizmann Institute, Rehovot, Israel (1969).

19. Tsu. T. T. and Herzenberg, L. A.: Solid-phase radioimmune assays. In: B. S. Mishell and S. M. Shiigi (eds): Selected Methods in Cellular Immunology, p. 373 (Freeman, San Francisco, California 1980).

20. Wilson, G. B.: Monospecific antisera, hybridoma antibodies, and immunoassays for cystic fibrosis protein. Lancet, 2: 313 (1980)

21. Wilson, G. B. and Floyd, E.: Detection and characterization of cystic fibrosis protein employing isoelectric focusing and immunoelectrophoretic techniques. In: R. C. Allen and P. Arnaud (eds): Electrophoresis '81, p. 529 (W. de Gruyter Inc.. Hawthorne, New York, New York 1981).

22. Wilson, G. B. and Fudenberg, H. H.: Further purification and characterization of serum proteins used to detect cystic fibrosis genotypes by isoelectric focusing. Texas Rep. Biol. Med., 34: 51 (1976).

23. Wilson, G. B. and Fudenberg, H. H.: Studies on cystic fibrosis using isoelectric focusing. IV. Distinction between ciliary dyskinesia activity in cystic fibrosis and asthmatic sera and association of cystic fibrosis protein with the activity in cystic fibrosis serum. Pediatr. Res., 11: 317 (1977).

24. We thank Dr. R. C. Beckerman for providing us with the CF blood specimens and Dr. Y. T. Li for his comments and suggestions.

25. Requests for reprints should be addressed to: Dr. Emmanuel Shapira. Head, Sections of Clinical and Biochemical Genetics, Department of Pediatrics, Tulane University School of Medicine, 1430 Tulane Avenue, New Orleans, LA 70112 .

26. This study was supported in part by a grant from the E. G. Schlieder Educational Foundation.

27. Received for publication January 13, 1982

28. Accepted for publication April 28. 1982. 